\title{
Investigating Rework: Insights from the Malaysian Construction Industry
}

\author{
Jeffrey Boon Hui Yap ${ }^{1 *}$ and Shi Min Tan² \\ ${ }^{1,2}$ Lee Kong Chian Faculty of Engineering and Science, Universiti Tunku Abdul Rahman (UTAR), Kajang, Malaysia
}

\begin{abstract}
Construction practitioners recognise that rework is undesirable due to the detrimental effects. While rework literature has examined rework causation factors in construction projects, the problem continues to plague the industry resulting in poor delivery performance. To better understand this phenomenon and given the scarcity of Malaysian-based rework study, a questionnaire survey involving 130 Malaysian construction practitioners (consultants, contractors and clients) were undertaken to obtain feedback about nature, implications, causes and solutions for rework. Data were analysed using descriptive statistical techniques to prioritise the variables studied. From the analyses, rework is a causal factor for delays and cost overruns, higher wastage and productivity inhibitor. The findings revealed the leading causes of rework are poor quality management, improper planning, lack of communication, design changes and poor subcontractor management. Some practical rework minimisation approaches are also suggested to better manage and prevent rework towards enhanced project performance.
\end{abstract}

Keywords: rework; construction industry; project management; schedule delay; cost overrun; Malaysia

\section{INTRODUCTION}

Rework remains a chronic problem undermining construction performance globally (Love et. al., 2020; Palaneeswaran et. al., 2014; Yap et. al., 2017, 2020; Ye et al., 2014). Previous research has indicated rework as a critical factor that can directly cause delays and cost overruns (Hwang \& Yang 2014; Hwang et. al., 2009; Josephson et al., 2002). According to Hwang et al. (2009), the cost of construction is often raised by $5 \%$ due to rework alone. In another study in Australia, Love and Edwards (2005) reported the mean direct and indirect cost of rework in relation to contract sum accounted for $6.7 \%$ and $5.9 \%$, respectively. In Singapore, Hwang and Yang (2014) observed rework as the primary factor of schedule growth. In this connection, frequent changes that result in additional work or simply rework much contributed to low labour productivity in India (Thomas \& Sudhakumar 2015). Given that $55 \%$ of Malaysian projects suffered from cost overruns (Shehu et al., 2014) and rework is a significant inhibitor factor for time and cost control, the persistence of the problem warrants more research efforts to gain more comprehensive understanding so practical rework minimisation strategies can be formulated.

There have been limited studies on rework causation and attributing rework to time-cost overruns in the Malaysian context. In this light, the first sensible step in improving project performance is to recognise the nature of rework and the negative implications to project outcomes. After determining the implications of rework, the second step is to assess the rework causation factors most relevant to the local construction so that some effective rework prevention approaches can be recommended, ultimately allowing the industry to improve overall construction performance. With this background, the aim of this paper will be achieved through the following objectives:

i. To investigate the nature and implications of rework;

ii. To identify and rank the causes of rework;

iii. To compare the Malaysian situation with some other selected countries; and

*Corresponding author's e-mail: bhyap@utar.edu.my 
iv. To examine the significance of potential rework reduction measures.

To achieve these objectives, a systematic review on rework was conducted to appreciate the interpretations, determinants of rework and some practical remedies. These salient rework issues were then appraised through a broad survey of Malaysian construction practitioners to provide much-needed insights to understand and address rework problems in the Malaysian construction industry and beyond.

\section{REWORK BACKGROUND}

A summary of the keywords used by various authors is presented in Table 1. Burati et al. (1992) associated rework with quality deviation factors while Love et al. (2015) deliberated non-conformances. Common predicaments associated with rework are defects (Sommerville, 2007), quality failures (Barber et al., 2002) and incompetency (Yap et al., 2019). It can be observed from Table 1 that rework involves doing the same thing more than once, which is considered non-value adding activity. It is worth to underscore that rework demands additional resources (i.e. time, cost, labour, materials, machinery) for abortive work that jeopardises project success. As such, doing it right the first time is the precursor for not reworking.

Table 1. Rework in construction

\begin{tabular}{|c|c|c|c|c|c|c|c|c|c|}
\hline & & & & & tho & & & & \\
\hline Keywords & 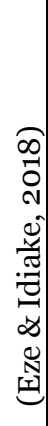 & 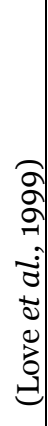 & 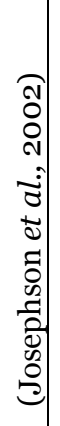 & 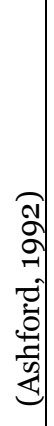 & $\begin{array}{c}3 \\
0 \\
0 \\
0 \\
0 \\
0 \\
0 \\
-0 \\
0 \\
0 \\
0 \\
0 \\
0 \\
0\end{array}$ & 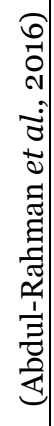 & 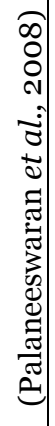 & 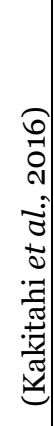 & 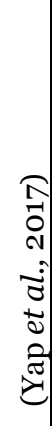 \\
\hline $\begin{array}{l}\text { Undesired and } \\
\text { unnecessary effort }\end{array}$ & $\sqrt{ }$ & $\sqrt{ }$ & & & & $\sqrt{ }$ & $\sqrt{ }$ & & $\sqrt{ }$ \\
\hline $\begin{array}{l}\text { Redoing a process or } \\
\text { activity }\end{array}$ & & $\sqrt{ }$ & & & & $\sqrt{ }$ & $\sqrt{ }$ & & $\sqrt{ }$ \\
\hline $\begin{array}{l}\text { Degrades the total } \\
\text { project performance }\end{array}$ & $\sqrt{ }$ & & $\sqrt{ }$ & & $\sqrt{ }$ & $\sqrt{ }$ & $\sqrt{ }$ & $\sqrt{ }$ & $\sqrt{ }$ \\
\hline $\begin{array}{l}\text { Non-conformance to } \\
\text { client's requirement } \\
\text { and expectation }\end{array}$ & & & & $\sqrt{ }$ & $\sqrt{ }$ & & & $\sqrt{ }$ & $\sqrt{ }$ \\
\hline $\begin{array}{l}\text { Correction to the } \\
\text { failure work }\end{array}$ & & $\sqrt{ }$ & & $\sqrt{ }$ & & & $\sqrt{ }$ & $\sqrt{ }$ & \\
\hline
\end{tabular}

\section{RESEARCH METHOD}

A detailed literature review was used to identify the nature of rework in construction and the implications of rework as well as a list of 20 most frequently cited causes of rework and nine potential approaches to minimise rework. A structured questionnaire was further developed based on the variables emerged and drafted in plain and simple language to seek the respondents' judgement on the variables. The questionnaire contained four parts: first, respondent's background information; second, an overview of rework in construction; third, rework causes and forth, seeming solutions for rework minimisation. A 5-item Likert scale was adopted to gauge the extent of agreement, with 1 being "strongly disagree" to 5 being "strongly agree". A total of 1005 e-survey forms were disseminated to construction practitioners nationwide. Of these, 130 valid responses were returned; reaching response rate of $12.94 \%$ where it is not uncommon for studies seeking feedback from the Malaysian construction industry. This is in accordance with Yong and Mustaffa (2013) and Abdul-Aziz (2012) recorded a low response rate of $9.83 \%$ and $10.33 \%$ respectively in which they attributed to busy work environment and apathy towards research in the local construction industry. Nonetheless, the sample size of 130 , which is greater than 100 is adequate for satisfactory statistical analysis and inference (Fellows \& Liu 2015; Yap et al., 2019). SPSS Statistics V23.0 statistical analysis software was used to analyse the data and prioritise the hypothesised variables accordingly.

\section{A. Respondent's Characteristics}

Table 2 provides detailed background information about the 130 respondents. The respondents included representatives from three primary construction stakeholders, viz. consultant (45.4\%), contractor (30.0\%) and client (24.6\%) to ensure capturing the perspectives of different project roles. Of the respondents, all had undergone tertiary education. Additionally, almost 30\% hold managerial or higher designations while $38.6 \%$ had more than 10 years of experience in the construction industry which indicated that the respondents had appropriate qualification and experience to offer sound judgement on the questionnaire. 
Table 2. Respondents' profile

\begin{tabular}{|c|c|c|c|}
\hline Parameter & Category & Response & $\begin{array}{c}\text { Frequency } \\
\text { (\%) }\end{array}$ \\
\hline \multirow[t]{3}{*}{ Role } & Consultant & 59 & $45 \cdot 4$ \\
\hline & Contractor & 39 & 30.0 \\
\hline & Client & 32 & 24.6 \\
\hline Working & $<5$ years & 57 & 43.8 \\
\hline \multirow[t]{4}{*}{ experience } & $6-10$ years & 23 & 17.7 \\
\hline & 11 - 15 years & 20 & 15.4 \\
\hline & $16-20$ years & 13 & 10.0 \\
\hline & $>20$ years & 17 & 13.1 \\
\hline Highest & High school & o & o \\
\hline \multirow[t]{4}{*}{ education } & Diploma & 19 & 14.6 \\
\hline & Degree & 83 & 63.8 \\
\hline & Master & 21 & 16.2 \\
\hline & $\mathrm{PhD}$ & 7 & $5 \cdot 4$ \\
\hline \multirow[t]{4}{*}{ Job position } & Junior executive & 51 & 39.2 \\
\hline & Senior executive & 42 & 32.3 \\
\hline & $\begin{array}{l}\text { Supervisor/ } \\
\text { manager }\end{array}$ & 26 & 20.0 \\
\hline & Director & 11 & 8.5 \\
\hline
\end{tabular}

\section{B. Data Reliability}

The internal consistency of questionnaire items was tested using Cronbach's a to ensure metric reliability. The computed a coefficient values were 0.863 for perceptions towards rework ( 5 items), 0.769 for impacts of rework ( 7 items), 0.886 for rework causes (20 items) and 0.854 for potential rework minimisation approaches ( 9 items); all were found to be greater than 0.70 whereby the data can be regarded as reliable (Yan et. al., 2019; Yap et al., 2019).

\section{RESULTS AND DISCUSSION}

\section{A. Perceived Rework Problems and Impacts}

Table 3 shows the mean and standard deviation for the understanding of rework in construction. The majority of the respondents agreed that rework is associated with non-value adding activity where the three most perceived rework problems are related to "redoing a process or activity", "correction to the failure work" and "non-conformance to client's requirement and expectation". These findings are consistent with the definition of rework, as discussed above.

Table 3. Nature of rework

\begin{tabular}{cccc}
\hline Nature & Mean & SD & Rank \\
\hline Redoing a process or activity & 4.008 & 0.821 & 1 \\
\hline
\end{tabular}

\begin{tabular}{lccc}
$\begin{array}{l}\text { Correction to the failure work } \\
\begin{array}{l}\text { Non-conformance to client's } \\
\text { requirement and expectation }\end{array}\end{array}$ & 3.854 & 0.957 & 2 \\
$\begin{array}{l}\text { Degrades the total project } \\
\text { performance }\end{array}$ & 3.477 & 0.894 & 3 \\
$\begin{array}{l}\text { Undesired and unnecessary } \\
\text { work }\end{array}$ & 3.477 & 0.950 & 5 \\
\hline
\end{tabular}

Regarding the impacts of rework, Table 4 indicates the ratings provided by the respondents. Global studies have elucidated rework as an endemic phenomenon that can significantly undermine project success and team morale (Kakitahi et. al., 2016; Love et. al., 2009; Ye et al., 2014). A closer examination of Table 4 reveals the three most detrimental implications to Malaysian projects include "time and cost overruns", "contribute to construction waste" and "low productivity". According to Yap et al. (2017) Malaysianbased study, rework raises construction cost by up to $6 \%$ and delays schedule by practically 5-10\%. In Ugandan public projects, rework impacted project budget and schedule by nearly $4.5 \%$ and $8.4 \%$, respectively (Kakitahi et al., 2016). Additionally, rework negatively impact organisational performance. The need to rework degrades workers' morale, disturb work rhythm, increase stress level and can cause high absenteeism (Hanna et. al., 2005; Yap et al., 2018). Thus, labour productivity is adversely impacted.

Table 4. Ranking of impacts of rework

\begin{tabular}{lccc}
\hline Implications & Mean & SD & Rank \\
\hline Time and cost overrun & 4.454 & 0.648 & 1 \\
Contributed to construction & 4.231 & 0.753 & 2 \\
waste & & & \\
Low productivity & 4.146 & 0.808 & 3 \\
Quality deviation & 4.092 & 0.782 & 4 \\
Disputes & 4.077 & 0.700 & 5 \\
Delay in progress payment & 3.954 & 0.870 & 6 \\
Poor safety & 3.569 & 0.797 & 7 \\
\hline
\end{tabular}

\section{B. Rework Causes in Construction}

Ranked in descending order, Table 5 presents the significance score for each cause. When two or more causes obtained the same mean score, the cause that obtained a smaller standard deviation is regarded as more significant (Yap et al., 2018). Twelve of the causes obtained high mean scores greater than 4.o, which are considered as very significant in the rating 
scale whereas the other eight causes are also rated as significant with mean scores of higher than 3.0. The leading causes of rework are poor quality management (mean=4.300), improver planning $($ mean=4.292), lack of communication (mean=4.246), design changes (mean=4.246) and poor subcontractor management (mean=4.192). Similarly, Love et al. (2009) investigated rework using data from 260 completed building and infrastructure projects in Australia to observe that inadequate emphasis on quality management mechanism contributed to higher rework costs in the projects sampled.

The other contributors to rework costs are related to changes instructed by the client, site and subcontractor-related issues and flawed project communications. In a Swedish study, Josephson et al. (2002) grouped rework causes according to client, design, workmanship, material, machines and production management. Associating rework and schedule performance, Hwang and Yang (2014) reported that designrelated changes, deficient design coordination and improper site management as major factors undermining schedule performance. Additionally, high fragmentation of the construction industry contributes to an adversarial culture that also provokes frequent changes due to miscommunication and improper coordination, and ultimately continual rework (Yap et al., 2018).

Table 5. Ranking of rework causes

\begin{tabular}{|c|c|c|c|}
\hline Causes & Mean & SD & Rank \\
\hline $\begin{array}{l}\text { Poor quality } \\
\text { management }\end{array}$ & 4.300 & 0.552 & 1 \\
\hline Improper planning & 4.292 & 0.549 & 2 \\
\hline Lack of communication & 4.246 & 0.671 & 3 \\
\hline Design changes & 4.246 & 0.727 & 4 \\
\hline $\begin{array}{l}\text { Poor subcontractor } \\
\text { management }\end{array}$ & 4.192 & 0.636 & 5 \\
\hline $\begin{array}{l}\text { Poor and inefficient site } \\
\text { management }\end{array}$ & 4.185 & 0.680 & 6 \\
\hline $\begin{array}{l}\text { Lack of clarity in project } \\
\text { scope }\end{array}$ & 4.177 & 0.628 & 7 \\
\hline Lack of data & 4.169 & 0.661 & 8 \\
\hline Poor site coordination & 4.146 & 0.779 & 9 \\
\hline Lack of commitment & 4.092 & 0.652 & 10 \\
\hline Variation order & 4.069 & 0.673 & 11 \\
\hline
\end{tabular}

\begin{tabular}{|c|c|c|c|}
\hline Design error & 4.062 & 0.775 & 12 \\
\hline $\begin{array}{l}\text { Poor contract } \\
\text { documentation }\end{array}$ & 3.985 & 0.816 & 13 \\
\hline $\begin{array}{l}\text { Improper handling of } \\
\text { machinery and } \\
\text { equipment }\end{array}$ & 3.915 & 0.845 & 14 \\
\hline $\begin{array}{l}\text { Poor human resources } \\
\text { management }\end{array}$ & 3.892 & 0.780 & 15 \\
\hline $\begin{array}{l}\text { Improper handling of } \\
\text { materials and delivery }\end{array}$ & 3.854 & 0.836 & 16 \\
\hline Loss of biorhythm & 3.823 & 0.731 & 17 \\
\hline $\begin{array}{l}\text { Slips and lapses of } \\
\text { attention }\end{array}$ & 3.815 & 0.691 & 18 \\
\hline Time limitation & 3.669 & 0.893 & 19 \\
\hline Lack of motivation & 3.377 & 0.828 & 20 \\
\hline
\end{tabular}

The major rework causes identified in this study are also comparable with the primary delay factors in Malaysian and Indian construction industry as observed by Sambasivan and Soon (2007) and Doloi et al. (2012), respectively. In another Malaysian study, Yap et al. (2019) opined that the primary underlying reasons for schedule delays are uncontrolled design changes, project communication breakdown and incompetency of team members. Thus, it is sensible to infer that rework causation and construction time-cost overruns factors are reciprocal. With this in mind, generic strategies for reducing rework occurrences will lead to improved project performance.

A comparison of the five most important causes of rework among some selected countries is provided in Table 6 . The selected studies give a better understanding of the common rework causes in other countries and triangulate the findings of this current study in Malaysia. According to Olawale and Sun (2010), construction projects worldwide share some common characteristics but some issues may be countryspecific. Nonetheless, the major causes of rework cited in Table 6 are associated with poor project management practices in relation to planning, monitoring and control aspects. Additionally, lack of knowledge and expertise of the designers and site personnel often result in design and construction deficiencies. In light of this, rework causation is significantly influenced by the competency and experience of project personnel and workmanship of tradesmen. 
Table 6. Comparison with selected countries

\begin{tabular}{|c|c|c|c|c|c|}
\hline \multirow{2}{*}{$\begin{array}{l}\text { Location of } \\
\text { study } \\
\text { (Author) }\end{array}$} & \multicolumn{5}{|c|}{ Major causes } \\
\hline & 1 & 2 & 3 & 4 & 5 \\
\hline $\begin{array}{l}\text { Malaysia } \\
\text { (This study, } \\
\text { 2020) }\end{array}$ & $\begin{array}{l}\text { Poor quality } \\
\text { management }\end{array}$ & $\begin{array}{l}\text { Improper } \\
\text { planning }\end{array}$ & $\begin{array}{l}\text { Lack of } \\
\text { communication }\end{array}$ & Design changes & $\begin{array}{l}\text { Poor } \\
\text { subcontractor } \\
\text { management }\end{array}$ \\
\hline $\begin{array}{l}\text { Nigeria } \\
\text { (Oyewobi et } \\
\text { al., 2016) }\end{array}$ & Design errors & Design omissions & $\begin{array}{l}\text { Construction } \\
\text { errors }\end{array}$ & $\begin{array}{l}\text { Construction } \\
\text { omissions }\end{array}$ & Quality deviation \\
\hline $\begin{array}{l}\text { China (Ye et } \\
\text { al., 2014) }\end{array}$ & $\begin{array}{l}\text { Unclear and } \\
\text { ambiguous } \\
\text { project process } \\
\text { management }\end{array}$ & $\begin{array}{l}\text { Poor quality of } \\
\text { construction } \\
\text { technologies used }\end{array}$ & $\begin{array}{l}\text { Use of poor } \\
\text { construction } \\
\text { materials }\end{array}$ & $\begin{array}{l}\text { Active rework } \\
\text { made by the } \\
\text { contractors to } \\
\text { improve quality }\end{array}$ & $\begin{array}{l}\text { Design } \\
\text { error/omission } \\
\text { because of too } \\
\text { many design } \\
\text { tasks and time } \\
\text { boxing }\end{array}$ \\
\hline $\begin{array}{l}\text { Singapore } \\
\text { (Hwang } \\
\text { \& Yang, 2014) }\end{array}$ & $\begin{array}{l}\text { Design-related } \\
\text { change orders }\end{array}$ & $\begin{array}{l}\text { Poor design } \\
\text { coordination } \\
\text { between design } \\
\text { members }\end{array}$ & $\begin{array}{l}\text { Poor site } \\
\text { management } \\
\text { systems }\end{array}$ & $\begin{array}{l}\text { Poor } \\
\text { workmanship/ } \\
\text { lack of technical } \\
\text { skills }\end{array}$ & $\begin{array}{l}\text { Design errors and } \\
\text { omission }\end{array}$ \\
\hline $\begin{array}{l}\text { Canada (Fayek } \\
\text { et al., 2003) }\end{array}$ & $\begin{array}{l}\text { Consistency not } \\
\text { ensured before } \\
\text { issued for } \\
\text { construction }\end{array}$ & $\begin{array}{l}\text { Poor } \\
\text { workmanship of } \\
\text { the prefab } \\
\text { material }\end{array}$ & Lack of inspection & $\begin{array}{l}\text { Original design/ } \\
\text { specification was } \\
\text { incorrect }\end{array}$ & $\begin{array}{l}\text { Inadequate } \\
\text { discipline } \\
\text { coordination }\end{array}$ \\
\hline $\begin{array}{l}\text { Sweden } \\
\text { (Josephson et } \\
\text { al., 2002) }\end{array}$ & $\begin{array}{l}\text { Erroneous } \\
\text { workmanship }\end{array}$ & $\begin{array}{l}\text { Unsuitable or } \\
\text { faulty design }\end{array}$ & $\begin{array}{l}\text { Lack of } \\
\text { coordination }\end{array}$ & Late deliveries & $\begin{array}{l}\text { Mistakes in } \\
\text { planning }\end{array}$ \\
\hline
\end{tabular}

\section{Potential Rework Minimisation Approaches}

Table 7 presents the ranking of potential solutions to reduce rework in construction projects. A close examination of Table 7 reveals that all the recommended solutions except for design scope freezing are perceived as very significant with mean scores of higher than 4.o. Improve communication (mean=4.245), building information modelling (BIM) (mean=4.215) and flexibility in project management (mean=4.185) are seen as the three most effective measures; all relating to effective coordination processes for collective multi-stakeholders engagement.

Table 7. Rework minimisation measures

\begin{tabular}{lccc}
\hline Potential solutions & Mean & SD & Rank \\
\hline Improve communication & 4.254 & 0.686 & 1 \\
Building information & 4.215 & 0.610 & 2 \\
modelling (BIM) & & & \\
\hline
\end{tabular}

\begin{tabular}{lccc}
\hline $\begin{array}{l}\text { Flexibility in project } \\
\text { management }\end{array}$ & 4.185 & 0.785 & 3 \\
$\begin{array}{l}\text { Total quality management } \\
\text { (TQM) }\end{array}$ & 4.185 & 0.795 & 4 \\
$\begin{array}{l}\text { Implementing error } \\
\text { management }\end{array}$ & 4.177 & 0.687 & 5 \\
$\begin{array}{l}\text { Implementing preventive } \\
\text { maintenance }\end{array}$ & 4.131 & 0.652 & 6 \\
$\begin{array}{l}\text { Value management } \\
\text { Training }\end{array}$ & 4.131 & 0.719 & 7 \\
Design scope freezing & 4.008 & 0.858 & 8 \\
\hline
\end{tabular}

Stakeholder alignment at early phases of the project such as planning stage alleviates the likelihood of design changes at the latter part of the project (Aldhaheri et al., 2018). In this vein, project effectiveness can be achieved with proper synchronisation through timely and effective communication among project parties from differing background and 
expertise. Conversely, lack of communication hampers muchneeded coordination among various stakeholders, resulting in mistakes, omissions, conflicts and constructability predicaments which then demand further adjustments (rework). On another note, enhancing communication engenders collaboration needed to promote trust, collective decision-making and effective participation; leading to fewer changes in design and construction, ensuring compliance and quality of deliverables and enhancing project control (Yap et al., 2019). It is worth noting that communication, trust and knowledge sharing are intertwined; affecting shared learning among team members within and across projects. In this connection, the factors critical to project success include competence, strong commitment and effective communication (Yong \& Mustaffa, 2013).

In a recent Singapore-based study, Hwang et al. (2019) reported that projects that used building information modelling (BIM) tend to experience lower incidence, magnitude and impact of rework as compared to non-BIM projects. Moreover, information can be openly shared using BIM environment to support collaboration and change management (Matthews et al., 2018). However, the adoption of BIM is still lacklustre in the global construction industry attributable to reasons such as lack of relevant knowledge and expertise, technical issues and data ownership issues (Zhao et al., 2017). There are no one-size fits all approach for construction project management, particularly dealing with rework. As such, flexible and adaptable thinking, and situational problem-solving aptitudes are crucial due to dynamic products and processes in construction projects (Teerajetgul \& Chareonngam, 2008) to address the factors that may inflate rework incidence. Leveraging on reusable project knowledge and collective organisational learning, Yap and Skitmore (2020) emphasise continuously exploit best practices such as proven construction techniques and management processes to contain rework and enhance project performance.

\section{CONCLUSIONS}

Rework remains a pervasive and perennial problem in construction; demanding additional resources to perform non-value adding activities and leading to poor project performance. From a literature review, pertinent issues concerning rework in construction projects were identified. The opinions of construction practitioners about rework were obtained through a broad questionnaire survey. This study has identified the critical issues arising from rework. Poor quality management, improper planning, lack of communication, design changes and poor subcontractor management were listed as the top five most significant causes of rework. A comparison with some selected countries pointed out analogous rework causation factors, mostly attributed to persistent managerial problems. This study has also determined the most effective rework minimisation measures comprise improving communication, building information modelling (BIM) and flexibility in project management.

From these results, critical reflection about existing practices is needed to reduce rework. In this vein, the failure to learn and improve organisational and project performance is regarded as "functional stupidity" (Love et al., 2018), which results in recurring rework and project failures. Drawing on Pareto's 80/20 rule, addressing the five major causes of rework identified in this study can contain rework to a considerable extent. Thus, the findings could help construction fraternity to gain better insights about the criticality and root causes of rework in their present and future projects. Recognising the nature, impacts and most probable causes for rework will induce the construction industry to devise strategies to manage and prevent rework towards improved project performance. The proactive control measures prescribed are useful for preventing rework incidence in practice.

While this research makes several contributions to recognise rework as an unnecessary abortive activity that can adversely affect time, cost, quality and productivity performance as well as resulting in higher wastage, some limitations should be noted. The majority of the respondents are from consultant organisations which may skew the results towards the consultant's perspective. The low response rate and relatively small sample size restrict generalisation but can support the indicative quantitative observation. Additionally, data collection was facilitated using a single approach via a questionnaire survey. Therefore, future research can include a more balanced representation of construction professionals with enlarged sample size. The use 
of qualitative approaches such as case studies and in-depth interviews allow participants to provide more detailed explanation through story-telling about rework-related issues in the projects that they involved. The richness of the data enables mapping of the interdependent cause-and-effect relationships beyond single-cause identification. As suggested by Yap et al. (2019), deepened mental models about phenomenon causation using retrospective sensemaking and systemic thinking approaches are likely to increase the ability to learn and influence current practices towards the construction industry transformation agenda.

\section{REFERENCES}

Abdul-Aziz, A-R 2012, 'Control mechanisms exercised in Malaysian housing public-private partnerships', Construction Management and Economics, vol. 30, no. 1, pp. 37-55.

Abdul-Rahman, H, Wang, C \& Yap, JBH 2016, 'Impacts of design changes on construction project performance: insights from a literature review', Journal of Quantity Surveying \& Construction Business, vol. 7, no. 1, pp. 31-54. Aldhaheri, M, Bakchan, A \& Sandhu, MA 2018, 'A structural equation model for enhancing effectiveness of engineering, procurement and construction (EPC) major projects: enduser's perspective', Engineering, Construction and Architectural Management, vol. 25, no. 9, pp. 1226-1252.

Ashford, JL 1992, 'The management of quality in construction', E \& F Spon, London.

Barber, P, Graves, A, Hall, M, Sheath, D \& Tomkins, Cb2002, 'Quality failure costs in civil engineering projects', International Journal of Quality \& Reliability Management, vol. 17 , no. 4/5, pp. 479-492.

Burati, JL, Farrington, JJ \& Ledbetter, WB 1992, 'Causes of quality deviations in design and construction', Journal of Construction Engineering and Management, vol. 118, no. 1, pp. 34-49.

Doloi, H, Sawhney, A, Iyer, KC \& Rentala, S 2012, 'Analysing factors affecting delays in Indian construction projects', International Journal of Project Management, vol. 30, no. 4, pp. 479-489.

Eze, EC \& Idiake, JE 2018, 'Analysis of cost of rework on time and cost performance of building construction projects in Abuja, Nigeria', International Journal of Built Environment and Sustainability, vol. 5. no. 1, pp. 56-67.

Fayek, AR, Dissanayake, M \& Campero, O 2003, Measuring and classifying construction field rework: a pilot study, May 2003, University of Alberta, Canada.

Fellows, R \& Liu, A 2015, Research methods for construction, John Wiley \& Sons, Ltd., UK, Oxford, UK.

Hanna, AS, Menches, CL, Sullivan, KT \& Sargent, JR 2005,
'Factors affecting absenteeism in electrical construction', Journal of Construction Engineering and Management, vol. 131, no. 11, pp. 1212-1218.

Hwang, B-G \& Yang, S 2014, 'Rework and schedule performance: a profile of incidence, impact, causes and solutions', Engineering, Construction and Architectural Management, vol. 21, no. 2, pp. 190-205.

Hwang, B, Thomas, S, Haas, C \& Caldas, C 2009, 'Measuring the impact of rework on construction cost performance', Journal of Construction Engineering and Management, vol. 135, no. 3, pp. 187-198.

Hwang, B, Zhao, X \& Yang, KW 2019, 'Effect of BIM on rework in construction projects in Singapore: status quo, magnitud , impact, and strategies', Journal of Construction Engineering and Management, vol. 145, no. 2, pp. 04018125.

Josephson, P-E, Larsson, B \& Li, H 2002, 'Illustrative benchmarking rework and rework costs in Swedish construction industry', Journal of Management in Engineering, vol. 18, no. 2, pp. 76-83.

Kakitahi, JM, Alinaitwe, HM, Landin, A \& Mone, SJ 2016, 'Impact of construction-related rework on selected Ugandan public projects', Journal of Engineering, Design and Technology, vol. 14, no. 2, pp. 238-251.

Love, PED \& Edwards, DJ 2005, 'Calculating total rework costs in Australian construction projects', Civil Engineering and Environmental Systems, vol. 22, pp. 11-27.

Love, PED, Edwards, DJ, Smith, J \& Walker, DHT 2009, 'Divergence or congruence? A path model of rework for building and civil engineering projects', Journal of Performance of Constructed Facilities, vol. 23, no. 6, pp. $480-488$.

Love, PED, Matthews, J \& Fang, W 2020, 'Rework in construction: a focus on error and violation', Journal of Construction Engineering and Management, vol. 146, no. 9, pp. 0602001.

Love, PED, Smith, J, Ackermann, F \& Irani, Z 2018, 'The praxis of stupidity: an explanation to understand the 
barriers mitigating rework in construction', Production Planning \& Control, vol. 29, no. 13, pp. 1112-1125.

Love, PED, Smith, J \& Li, H 1999, 'The propagation of rework benchmark metrics for construction', International Journal of Quality \& Reliability Management, vol. 16, no. 7, pp. 638-658.

Love, PED, Teo, P, Carey, B, Sing, C \& Ackermann, F 2015, 'The symbiotic nature of safety and quality in construction: incidents and rework non-conformances', Safety Science, vol. 79, pp. 55-62.

Matthews, J, Love, PED, Mewburn, J, Stobaus, C \& Ramanayaka, C 2018, 'Building information modelling in construction: insights from collaboration and change management perspectives', Production Planning and Control, vol. 29, no. 3, pp. 1-15.

Olawale, YA \& Sun, M 2010, 'Cost and time control of construction projects: inhibiting factors and mitigating measures in practice', Construction Management and Economics, vol. 28, no. 5, pp. 509-526.

Oyewobi, LO, Abiola-Falemu, O \& Ibironke, OT 2016, 'The impact of rework and organisational culture on project delivery', Journal of Engineering, Design and Technology, vol. 14, no. 2, pp. 214-237.

Oyewobi, LO, Ibironke, OT \& Ganiyu, BO 2011, 'Evaluating rework cost- a study of selected building projects in Niger State, Nigeria', Journal of Geography, vol. 4, pp. 147-151.

Palaneeswaran, E, Love, PED, Kumaraswamy, MM \& Ng, TST 2008, 'Mapping rework causes and effects using artificial neural networks', Building Research and Information, vol. 36 , no. 5 , pp. $450-465$.

Palaneeswaran, E, Love, PED, Kumaraswamy, MM \& Ng, TST 2014, 'Causal ascription of rework in building and civil engineering projects: a multivariate exploration', Engineering, Construction and Architectural Management, vol. 21, no. 1, pp. 111-126.

Sambasivan, M \& Soon, YW 2007, 'Causes and effects of delays in Malaysian construction industry', International Journal of Project Management, vol. 25, no. 5, pp. 517-526.

Shehu, Z, Endut, IR, Akintoye, A \& Holt, GD 2014, 'Cost overrun in the Malaysian construction industry projects: a deeper insight', International Journal of Project Management, vol. 32, no. 8, pp. 1471-1480.

Sommerville, J 2007, 'Defects and rework in new build: an analysis of the phenomenon and drivers', Structural Survey, vol. 25, no. 5, pp. 391-407.

Teerajetgul, W \& Chareonngam, C 2008, 'Tacit knowledge utilization in Thai construction projects', Journal of
Knowledge Management, vol. 12, no. 1, pp. 164-174.

Thomas, AV \& Sudhakumar, J 2015, 'Factors influencing construction labour productivity: an Indian case study', Journal of Construction in Developing Countries, vol. 20, no. 2, pp. 53-68.

Yan, H, Elzarka, H, Gao, C, Zhang, F \& Tang, W 2019, 'Critical success criteria for programs in China: construction companies' perspectives', Journal of Management in Engineering, vol. 35, no. 1, 04018048.

Yap, JBH, Abdul-Rahman, H \& Wang, C 2018, 'Managing design change dynamics in building construction: conceptualising a qualitative model', Malaysian Construction Research Journal, vol. 5, no. 3, pp. 1-13.

Yap, JBH, Abdul-Rahman, H, Wang, C \& Skitmore, M 2018. 'Exploring the underlying factors inducing design changes during building production', Production Planning \& Control, vol. 29, no. 7, pp. 586-601.

Yap, JBH, Chong, JR, Skitmore, M \& Lee, WP 2020, 'Rework causation that undermines safety performance during production in construction', Journal of Construction Engineering and Management, vol. 146, no. 9, 04020106.

Yap, JBH, Chow, IN \& Shavarebi, K 2019, 'Criticality of construction industry problems in developing countries: analyzing Malaysian projects', Journal of Management in Engineering, vol. 35, no. 5, pp. 04019020.

Yap, JBH, Low, PL \& Wang, C 2017, 'Rework in Malaysian building construction: impacts, causes and potential solutions', Journal of Engineering, Design and Technology, vol. 15 , no. 5, pp. 591-618.

Yap, JBH \& Skitmore, M 2020, 'Ameliorating time and cost control with project learning and communication management Leveraging on reusable knowledge assets', International Journal of Managing Projects in Business, vol. 13, no. 4, pp. 767-792.

Yap, JBH, Skitmore, M, Gray, J \& Shavarebi, K 2019, 'Systemic view to understanding design change causation and exploitation of communications and knowledge', Project Management Journal, vol. 50, no. 3, pp. 288-305.

Ye, G, Jin, Z, Xia, B \& Skitmore, M 2014, 'Analyzing causes for reworks in construction projects in China', Journal of Management in Engineering, vol. 31, no. 6, pp. 04014097.

Yong, YC \& Mustaffa, NE 2013, 'Critical success factors for Malaysian construction projects: an empirical assessment', Construction Management and Economics, vol. 31, no. 9, pp. 959-978.

Zhao, X, Feng, Y, Pienaar, J \& O’Brien, D 2017, 'Modelling paths of risks associated with BIM implementation in 
architectural, engineering and construction projects', Architectural Science Review, vol. 6o, no. 6, pp. 472-482. 